\title{
Effect of pre storage treatments on the shelf-life of fresh cut carrots
}

\section{Thushara T. Chandran* and C. Mini}

Department of Processing Technology, College of Horticulture, College of Agriculture, Vellayani, THIRUVANANTHAPURAM (KERALA) INDIA (Email: thush.chandra@ gmail.com)

SUMMARY :

Fresh carrots collected from the local market were used for the study. Freshly collected carrots were washed, surface sanitized using the standardized $30 \mathrm{ppm}$ sodium hypo chlorite solution, outer skin scraped, washed and shreds were prepared and these shreds were air dried and kept in aluminiumtrays wrapped with cling film under refrigerated storage for taking observations. The physical, physiological and chemical quality parameters were analyzed and based on the microbial analysis it was found that 2 per cent calcium ascorbate as the best effective chemical treatment for shredded carrots.

KEY WORDS : Pre storage treatments, Fresh cut vegetables, Carrot, Nutritional quality, Shelf-life

How to cite this paper : Chandran, Thushara T. and Mini, C. (2014). Effect of pre storage treatments on the shelf-life of fresh cut carrots. Internat. J. Proc. \& Post Harvest Technol., 5 (2) : 114-119. 